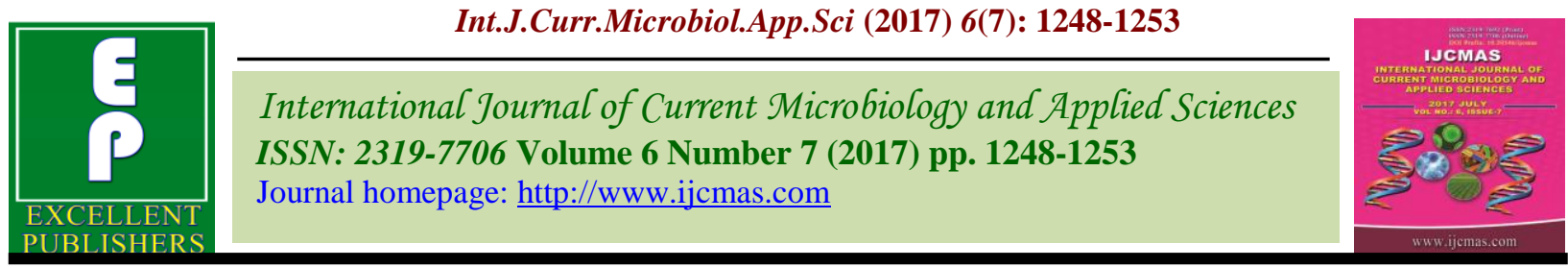

Original Research Article

https://doi.org/10.20546/ijcmas.2017.607.151

\title{
Agronomic Evaluation of Certified Organic Wheat (Triticum aestivum L.)
}

\author{
Mithilesh* and Thomas Abraham \\ Department of Agronomy, NAI, SHUATS, Allahabad (UP) 211007, India \\ *Corresponding author
}

A B S T R A C T

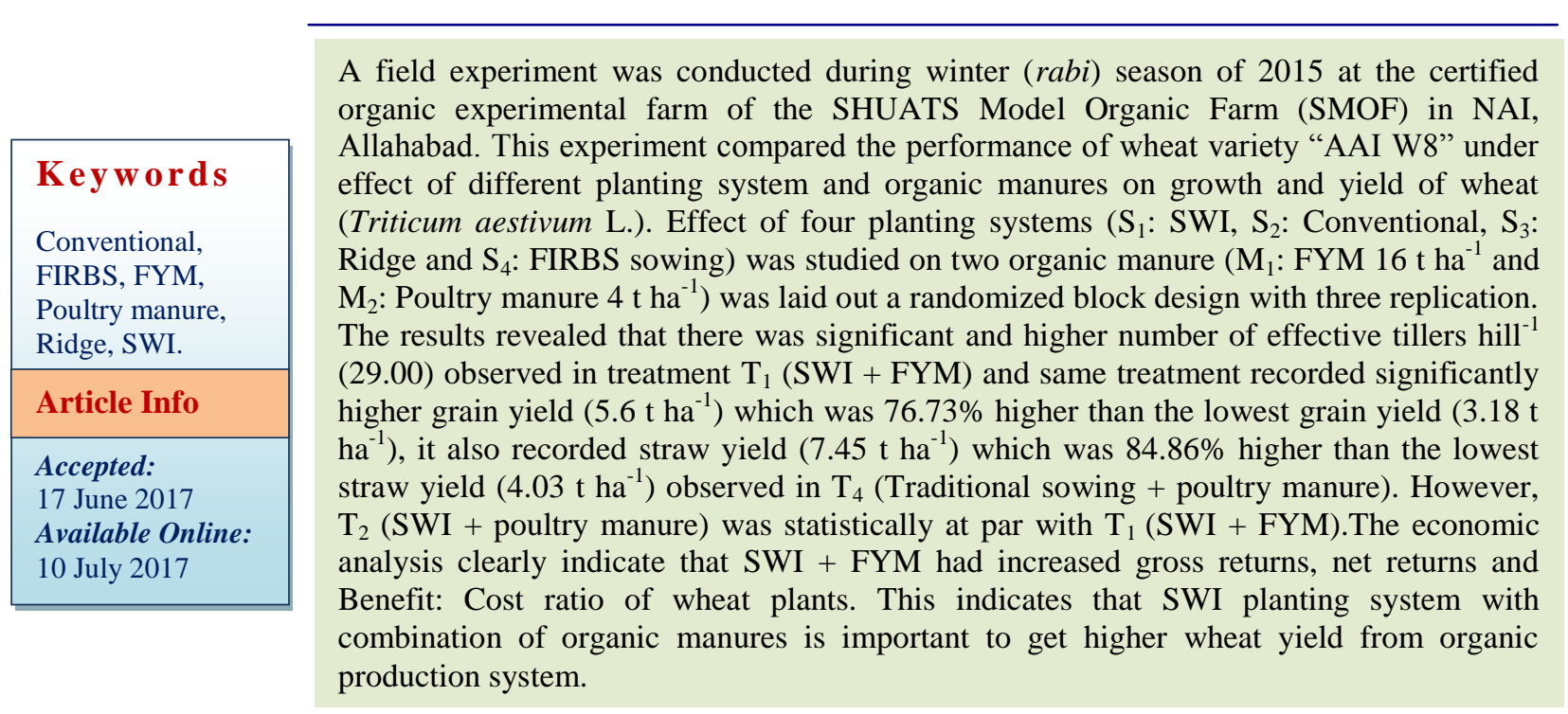

\section{Introduction}

In the anxiety of increasing food production to meet the needs of ever-increasing population of the country, there had been excessive use of agrochemicals for the last 50 years, and least attention was given to ecological agriculture. Consequently, the danger signals have started coming sooner than expected. Many of our highly productive soils have started showing signs of declining productivity. The prolonged and over-use of chemicals than crop requirement resulted in human health hazards and imbalance in natural resources. In this context, a keen awareness has to be created on the adoption of organic farming as a remedy to maneuver the ill-effects from chemical farming. The total nutritional consumption (NPK) from chemical fertilizers is about 25.54 million tones (Department of Fertilizers 2012-13) in India.

Sustainability refers to agricultural practices technically appropriate, economically and environmentally viable that meets society needs for food, feed, ecosystem services and human health for present and future generations (FAO 1995). To substitute the same, enough organic sources like cow dung, crop residues etc. are available with us. Thus, organic farming has a good potential under 
Indian context and this approach will conserve natural resources also. Kshirsagar and Abraham (2012) also reported that beneficial influence of organic manures as superior and efficient source of nutrient may have enable the partitioning of dry matter into the economic parts.

The causes of low productivity governed by so many factors like, weather (low and high temperature stress, high $\mathrm{RH}$ and drought), soil factors (soil texture, soil $\mathrm{pH}, \mathrm{EC}$ and available nutrients), availability of inputs like quality seed, irrigation, fertilizers and technologies of production being followed. Method of planting system plays very important role providing for the proper space required by plant for efficient utilization of Air, Water, Solar energy and nutrients, therefore, the crop yield and quality of the produce may be improved to great extent (Makwana et al., 2008). So, ridge planting pattern, method have been reported to be better for crop establishment and also water saving (Kshirsagar and Abraham, 2012).

The potential benefits of raised beds may be in terms of higher yield and water use efficiency and system of wheat intensification (SWI) method has also provide a great potential to increase wheat productivity and creates a very good growing condition through modified soil, water, sowing method, plant and nutrient management. SWI and some modified SWI interventions may give $54 \%$ more yield than available best conventional sowing practices (Uphoff et al., 2011). Planting technique is of considerable importance among the agronomic practices, as appropriate adjustment of plants in the field, may not only ensure optimum plant population but also enable the plants to exploit the land and other input resources more efficiently. Therefore, an experiment was conducted to study performance of wheat with different planting system and organic sources of nutrition in terms of growth and development, yield attributes and yield.

\section{Materials and Methods}

Exhaustive wheat crop experiment was taken in rabi season during 2015-16 on a sandy clay loam soil having $\mathrm{pH} 7.10$, organic carbon $0.45 \%$, medium in available NPK (284.60, $18.00257 .00 \mathrm{~kg} \mathrm{ha}^{-1}$ ) electrical conductivity (EC) of $0.28 \mathrm{dS} / \mathrm{m}$, at certified organic farm, SHIATS Model Organic Form(SMOF), Naini Agricultural Institute, Samhiggin Bottom University of Agricultural Technology and Sciences, Allahabad. Climate of the region is sub-tropical and semi-arid climate with the monsoon commencing from July and withdrawing by the end of September. For the intended study 8 treatments were tested under three replications by using randomized block design. Four planting system viz., SWI, conventional, ridge and FIRBS were applied through two organic manure i.e., FYM and poultry manure. Recommended dose of NPK (120:80:60) were applied through FYM @ 16 t ha ${ }^{-1}$ and poultry manure @ 4 t ha ${ }^{-1}$ for $80 \mathrm{~kg}$ $\mathrm{N}$ and remaining $40 \mathrm{~kg}$ nitrogen applied over fish amino acid @ 2.5\% and panchgavya @ $3 \%$.The farm yard manure and poultry manure doses were mixed in the soil before sowing and fish amino acid and panchgavya were used as foliar application on the crop at 30, 45 and 60 DAS. The wheat variety 'AAIW8' was selected for experiment. The seeds were sown are dibbling sowing with the spacing of $22.5 \mathrm{~cm} \times 10 \mathrm{~cm}$ except SWI. In SWI system two sprouted seeds hill $^{-1}$ were sown $20 \times 20 \mathrm{~cm}$ apart. Seeds were treated using luke warm water followed by dipping the $5 \mathrm{~kg}$ of seed in 10 litre of luke warm water to remove lighter seeds and impurities. For the SWI planting, remaining seeds were treated with a biological mixture of 3 litre of cow (indigenous) urine, $2 \mathrm{~kg}$ of jiggery and 2 $\mathrm{kg}$ of vermicompost well-mixed together in an earthen pot with 10 liters of warm water 
$\left(60^{\circ} \mathrm{C}\right)$. The seeds were soaked in this mixture for 6-8 hours. The seeds were then kept separated from the mixture by filtration and washed with clean water. The treated seeds were then kept in the shade for 10-12 hours, wrapped in rough lins (gunny bag), and during this period the seeds fully sprouted. The crop was irrigated with four irrigations at critical stages.

To provide weed free condition during critical growth period of crop and under SWI plots weeds was managed by incorporating them into the soil twice at 20 and 35 DAS with the help of cono-weeder.

Crop was harvested in the first week of April. The data on various growth, yield attributes and yield were recorded in different treatments. All the data were statistically analysed.

\section{Results and Discussion}

\section{Dry weight $\left(\mathrm{g} \mathrm{hill}^{-1}\right)$}

Both the test methods viz., SWI + FYM and poultry manure influenced the performance of wheat favorably (Table 1). These methods recorded significantly higher dry weight $\left(57.59 \mathrm{~g} \mathrm{hill}^{-1}\right)$ However, treatment $\mathrm{T}_{2}(\mathrm{SWI}+$ poultry manure) was found statistically at par with $\mathrm{T}_{1}$ (SWI + FYM). Khadka et al., 2012also reported similar result in wheat production.

\section{Yield attributes}

The yield attributes of wheat, viz. number of effective tillers and test weight were positively influenced by the different planting system, viz., SWI planting along with the addition of different organic manures, i.e., FYM and poultry manure (Table 1). Treatment $\mathrm{T}_{1}$ (SWI + FYM) resulted in significant increase in number of effective tillers hill $^{-1}$ (29.0) and test weight (45.65 g) and it was $53.79 \%$ in $9.84 \%$ higher compared to the lowest effective tillers hill ${ }^{-1}$ (13.40) and test weight $(41.56 \mathrm{~g})$ observed in the treatment $\mathrm{T}_{4}$ (conventional sowing + poultry manure). However, treatment $\mathrm{T}_{2}$ (SWI + poultry manure) was found statistically at par with $\mathrm{T}_{1}$ (SWI + FYM). The yielding attributing parameter enhanced due to these methods corroborate well with those of Bhargav et al., (2016) and Suryawanshi et al., (2014). Improvement in dry weight and yield attributes viz., plant height, number of effective tillers, test weight etc. by use of organic manures. Application of organic manures may be assigned to the fact that proper mineralization of these manures supplied available pant nutrients directly to plants and also had a solubilizing effect on fixed form of nutrients in soil. This similar finding is corroborated till of Raghuwanshi et al., (1994).

The expression of higher dry weight and higher yield parameter, i.e., effective tillers and test weight may be due to the better concurrent utilization of moisture, nutrients and solar radiation as well as orientation of the leaves, thereby leading to greater amount of photosynthesis. This finding is supported by Suryawanshi et al., (2014). So it's prominent to more dry matter accumulation of plant. SWI planting system has very high resilience to the hazards of climate change.

However, the SWI plots in the current experiment showed up to $50 \%$ tolerance to lodging and associated damages (shrinking of grain). Crops with larger, more effective root systems in association with more abundant and diverse life in the soil are more resilient when subjected to drought, storm damage and other climatic hazards. Buffering of such effects has been seen frequently with SRI management for rice (Uphoff, 2012). These finding are also corroborate with Dhar et al., (2014) in wheat crop at NWPZ of India. 
Int.J.Curr.Microbiol.App.Sci (2017) 6(7): 1248-1253

Table.1 Effect of different planting system and organic manures on dry weight, yield attributes, yield and economic of wheat at harvest stage

\begin{tabular}{|c|c|c|c|c|c|c|c|}
\hline Treatment & $\begin{array}{l}\text { Dry weight } \\
\quad\left(\mathrm{g} \mathrm{hill}{ }^{-1}\right)\end{array}$ & $\begin{array}{c}\text { No. of effective } \\
\text { tillers hill }{ }^{-1} 90 \\
\text { DAS }\end{array}$ & $\begin{array}{c}\text { Test weight } \\
\text { (g) }\end{array}$ & $\begin{array}{c}\text { Grain yield } \\
\qquad\left(\mathrm{t} \mathrm{ha}^{-1}\right)\end{array}$ & $\begin{array}{c}\text { Straw yield } \\
\left(\mathrm{t} \mathrm{ha}^{-1}\right)\end{array}$ & Net return & $\mathrm{B}: \mathrm{C}$ ratio \\
\hline $\mathrm{T}_{1} \mathrm{SWI}+\mathrm{FYM}$ & 57.59 & 29.00 & 45.65 & 5.62 & 7.45 & 58190.00 & 2.20 \\
\hline $\mathrm{T}_{2} \mathrm{SWI}+\mathrm{PM}$ & 55.22 & 26.67 & 45.26 & 5.36 & 7.37 & 54083.00 & 2.12 \\
\hline $\mathrm{T}_{3}$ Conventional $+\mathrm{FYM}$ & 24.65 & 14.13 & 42.62 & 3.29 & 4.20 & 15810.00 & 1.34 \\
\hline $\mathrm{T}_{4}$ Conventional $+\mathrm{PM}$ & 22.79 & 13.40 & 41.56 & 3.18 & 4.03 & 9590.00 & 1.30 \\
\hline $\mathrm{T}_{5}$ Ridge + FYM & 29.03 & 15.67 & 42.67 & 4.22 & 5.48 & 27475.00 & 1.69 \\
\hline $\mathrm{T}_{6}$ Ridge + PM & 26.57 & 15.30 & 42.56 & 3.89 & 5.11 & 21985.00 & 1.57 \\
\hline $\mathrm{T}_{7} \mathrm{FIRBS}+\mathrm{FYM}$ & 27.33 & 15.20 & 42.49 & 4.03 & 5.13 & 24490.00 & 1.62 \\
\hline $\mathrm{T}_{8} \mathrm{FIRBS}+\mathrm{PM}$ & 24.88 & 15.37 & 42.15 & 4.06 & 5.37 & 24790.00 & 1.64 \\
\hline F test & $\mathrm{S}$ & $\mathrm{S}$ & $\mathrm{S}$ & $\mathrm{S}$ & S & $\mathrm{S}$ & S \\
\hline SEm \pm & 0.48 & 0.50 & 0.47 & 0.15 & 0.24 & 4007.13 & 0.06 \\
\hline $\mathrm{CD}(\mathrm{P}=0.05)$ & 1.47 & 1.50 & 1.44 & 0.46 & 0.73 & 12154.36 & 0.19 \\
\hline $\mathrm{CV}$ & 2.50 & 4.74 & 1.91 & 6.18 & 7.53 & 23.49 & 6.35 \\
\hline
\end{tabular}




\section{Yield}

The grain yield $\left(5.62 \mathrm{t} \mathrm{ha}^{-1}\right)$ and straw yield $\left(7.45 \mathrm{tha}^{-1}\right)$ of wheat was significantly higher with (SWI + FYM) followed by other treatments of planting system and organic manure. However, Treatment $\mathrm{T}_{2}(\mathrm{SWI}+\mathrm{PM})$ was found statistically at par with treatment $\mathrm{T}_{1}$ (SWI + FYM). Abraham et al., 2014 reported an increase of $18-67 \%$ grain and 9$27 \%$ straw yield of wheat at farmer's field in SWI as compare to broadcast method.

The higher yield may be due to the fact that these organic manures supply direct available nutrients such as nitrogen to the plants and these organic manures improve the proportion of water holding stable aggregates of the soil (Gowda et al., 2007). Handrix et al., (1994) and Martens et al., (1992) also reported that organic manures attributing to cementing action of polysaccharides and other organic compounds released during the decomposition of organic matters, thus leading to vegetative and reproductive stages and in turn the final yield and SWI, increased crop production which may be due to enhanced the healthy roots and more productive tillers were systematic sowing of seed at fixed spacing, compared to the conventional broadcasting method may have reduced competition among the plants. Further, adequate availability of sunlight, water, nutrients and proper aeration may have due to good tillering and high production. Similarbeneficial effect on yield of wheat has been also reported by Bhargav et al., (2016) and Dhar et al., (2015).

\section{Economics}

The highest gross returns ( $₹ 105660.00 \mathrm{ha}^{-1}$ ), net returns (₹ $58190.00 \mathrm{ha}^{-1}$ ) and the benefit cost ratio (2.20) were recorded in treatment $T_{1}$ (SWI + FYM), which was $40.90 \%$ higher B: $\mathrm{C}$ when compared to the lowest value of
(1.30) in treatment $\mathrm{T}_{4}$ (Conventional $+\mathrm{PM}$ ). However, treatment $\mathrm{T}_{2}$ (SWI + poultry manure) was found to be statistically at par with treatment $\mathrm{T}_{1}(\mathrm{SWI}+\mathrm{FYM})$.

The seed rate used under SWI $\left(25 \mathrm{~kg} \mathrm{ha}^{1}\right)$ is one-fourth when compared with other planting system viz., conventional, ridge and FIRBS (100 kg ha ${ }^{-1}$ ) resulting in valuable resources saving such as seed under these newer method. The higher grain and straw yield under the advanced system of planting, i.e., which were observed in the various agronomic traits led to enhanced net returns and benefit: cost ratio. This result is in accordance with findings of Dhar et al., (2015) and Suryawanshi et al., (2014) in wheat.

In conclusion, this experiment showed superior performance of SWI and FYM on all parameters measured, viz., plant height, effective tillers hill ${ }^{-1}(29)$, grain yield $(5,620$ $\left.\mathrm{kg} \mathrm{ha}^{-1}\right)$, straw yield $\left(7,450 \mathrm{~kg} \mathrm{ha}^{-1}\right)$ and $\mathrm{B}: \mathrm{C}$ ratio $(2.20 \%)$ compared with the other treatments. The above conclusion is a result of 1 year's work and may be considered for recommending to the farmers, after at least one more year's field trial.

\section{References}

Anonymous. (2012-13). Statistics, All India Area, production and yield of wheat (Triticum aestivum L.).Directorate of economics Statistics, http: /www.agriccoop.nic.in.

ChanchalBhargav, G. Deshmukh, S.D. Sawarkar, S.L. Alawa and JyotiAhirwar. 2016. The system of wheat intensification in comparison with conventional method of wheat line sowing to increase wheat yield with low input cost. Plant Archives Vol. 16 No. 2, 2016 pp. 801-804.

Hossan, Md. I., Islam Md. K., sufian, Md. A., 
Meisner, C.A. and Islam, Md. AS. 2006. Effect of planting methods and nitrogen levels on yield and yield attributs of wheat. J. Bio-sci.14: 127-30.

Hendrix, P.F., Callaham, M.A., Jr. and James, S.W., 1994. Ecology of nearetic earthworms in the Southern USA-I. Characteristics of diplocardia longa surface casts in grass, hardwood and pinc micro habitats on the lower pied mount of Georgia, Megadrilogica, 5:4551.

Indian Fertilizer Scenario 2013.Department of Fertilizers Ministry of Chemicals and Fertilizers Government of India.

Kale, R. D. and Bano, K. 1986.Field trials with vermicompost (Vee comp. E-83 UAS) on Organic fertilizer. Proc. Nation. Sem. Organic Waste Utilization, Vermicompost, Part B, Worms and Vermicomposting, pp. 151160.

Khadka RB, Raut P: System of Wheat Intensification (SWI): A new concept on low-input technology for increasing wheat yield in marginal land. Paper for European Union Food Facility Project: Lalitpur; 2012.

Kshirsagar, Satish, M., and Abraham, Thomas, 2012.Studies on the influence of different planting systems and varieties through organic management practices on yield attributes and yield of sesame. Green Farming, 3 (6): 670-673.

Mackwana, C.F. and Tank, D.A. 2008. Effect of methods of sowing and seed rate on yield and quality of irrigated durum wheat (Triticum durumL.) variety GW1139. Res. Crops9: 494-96.

Martens, D.A., Johanson, J.B. and Frankenberger, Jr. $\quad$ W.T., 1992.Production and persistence of soi enzymes with repeated addition of organic residues. Soil Sci., 153: 53-61.

P.K. Suryawanshi, J.B. Patel and N.M. Kumbhar 2014. Assessment of SWI techniques with varying nitrogen levels for improving yield and quality ao wheat (Triticum aestivum L.) Crop Res. 48 (1, 2, \& 3): 6-9.

Shiv Dhar, B.C. Barah, Abhay K. Vyas and Norman T. Uphoff., 2015.Comparing system of wheat intensification with standard recommended practices in the northwestern plain zone of India.Archive of Agronomy and Soil science, 2015.

Uphoff N, Kassam AH, Harwood R. 2011. SRI as a methodology for raising crop and water productivity: productive adaptations in rice agronomy and irrigation water management. Paddy Water Environ. 9:3-11.

Uphoff, N. (2012). Supporting food security in the 21 st century through resourceconserving increases in agricultural production. Agriculture and Food Security, 1:18.

\section{How to cite this article:}

Mithilesh and Thomas Abraham. 2017. Agronomic Evaluation of Certified Organic Wheat (Triticum aestivum L.). Int.J.Curr.Microbiol.App.Sci. 6(7): 1248-1253. doi: https://doi.org/10.20546/ijcmas.2017.607.151 